\title{
Pensar a multiplicidade na hiperconcisão ficcional: o microconto brasileiro contemporâneo (2000-2017)
}

\author{
Thinking multiplicity in fictional hyperconcision: \\ contemporary Brazilian flash fiction (2000-2017) \\ Pensar la multiplicidad en la hiperconcisión ficticia: \\ el microrelato brasileño contemporáneo (2000-2017)
}

Ana Sofia Marques Viana Ferreira

\section{Resumo}

Nascido do modernismo e das vanguardas históricas, o microconto é hoje um dos reflexos literários mais emblemáticos do modo de ser e estar do novo milénio, contando com uma produção bastante significativa na América Latina. Neste trabalho, analisamos o panorama atual do microconto brasileiro, atendendo às suas tendências mais representativas, assim como aos autores e às obras que, nas últimas décadas, consolidaram essas mesmas direções.

Palavras-chave: microconto, literatura brasileira contemporânea, pós-modernidade.

\begin{abstract}
Born of the modernist and avant-garde period, flash fiction is one of the most emblematic literary reflections on life in the new millennium, and Latin America plays a significant role in the production of this genre. In this paper, we analyze the current panorama of Brazilian flash fiction, examining its most representative tendencies and the authors and works that have contributed to these characteristics.
\end{abstract}

Keywords: flash fiction, Contemporary Brazilian Literature, postmodernity.

\begin{abstract}
Resumen
Nacido del modernismo y de las vanguardias históricas, el microrrelato es hoy uno de los reflejos literarios más emblemáticos del modo de ser y estar del nuevo milenio, contando con una producción muy significativa en América Latina. En este trabajo analizamos el panorama actual del microrrelato brasileño a partir de sus tendencias más representativas y de los autores y obras que en las últimas décadas han consolidado esas mismas direcciones.
\end{abstract}

Palabras-clave: microrrelato, literatura brasileña contemporânea, posmodernidad.

\section{Horizonte conceptual e contextual do microconto}

A revitalização e o surgimento de novos meios de expressão literária nas últimas décadas, advindos sobretudo da extensão do uso de procedimentos tecnológicos que vão além do uso do suporte papel, foram provavelmente um dos maiores desafios para a teoria e crítica literária contemporânea. Estas disciplinas, mais que nunca determinadas em acompanhar e analisar as manifestações literárias recentes, têm vindo a ser confrontadas com múltiplas e diversas expressões, às vezes complexas, dialogantes e devedoras de outros âmbitos artísticos, fazendo dispersar em larga escala o território de alcance analítico dos estudos literários. O microconto, discurso hiperbreve, propenso à concisão e à elipse, com potencial narrativo e sagazmente volátil e transgressor, trouxe um novo veio aos estudos literários, não só pelo seu notável crescimento no que se refere à proliferação em várias tradições literárias (sobretudo na hispano-americana), mas também por sua representatividade e contribuição para entender os modos de estar e pensar do ser humano de hoje. Aspectos como o posicionamento céptico, paradoxal ou contraditório do

\footnotetext{
"Universidad de Salamanca (USAL), Salamanca, Espanha. (Dorcid.org/0000-0001-6602-4126. E-mail: anaferreira@usal.es
} 
sujeito em relação ao mundo, bem como o cultivo de formas que fogem ao cânone, fraturam o princípio de unidade, manifestam uma propensão ao uso reiterado de procedimentos intertextuais e se servem de forma recorrente do humor e da ironia para marcar um posicionamento crítico subversivo e distanciador (Noguerol, 1996, p. 1), figuram como insígnias dos textos literários contemporâneos e penetram com desembaraço nestes tecidos microficcionais. Algumas das marcas que mais fazem cativar a recepção destes textos residem na capacidade de projetar, em tão parco número de palavras, qualidades como a codificação subliminar da mensagem, a perspicácia e subtileza com que se gere o conteúdo do texto, a insubmissão a regras e a aposta no seu potencial de sugestão e de imprevisibilidade. Se no âmbito espanhol e hispanoamericano são já incontáveis os estudos dedicados a supeditar uma visão global do fenómeno, no espaço lusófono possuímos ainda um escasso número de ensaios e publicações que se detém a estudar o microconto, quer seja na sua evolução histórica, quer seja enquadrando-o a partir de uma perspectiva generalizadora e situacional. Nas palavras de Márcio Almeida,

[...] a omissão dos autores brasileiros na análise microficcional feita no país, aliada ao desconhecimento da língua portuguesa [...] faz com que a produção nacional seja desconhecida no exterior onde cresce muito o interesse pela narrativa de ficção curta (Almeida, 2010, p. 6).

Atendendo a esta situação, pretendemos com este trabalho analisar o panorama atual do microconto brasileiro do novo milénio, aspirando a contribuir a uma maior elucidação desta categoria textual dentro do espaço lusófono. A riqueza e diversidade de propostas que apresenta atualmente este discurso literário no Brasil constitui a motivação principal deste estudo e permitirá a constatação de que o microconto brasileiro se sustenta em três grandes tendências: o microconto fantástico e maravilhoso, o microconto de extrema condensação linguística e o microconto que apresenta uma forte contiguidade ao género da crónica jornalística. Por uma questão de balizamento, atenderemos às publicações e às propostas surgidas entre 2000 e 2017, o que nos levará a considerar não apenas os novos escritores que se estreiam na publicação de obras que se inserem neste género, mas sobretudo aqueles escritores que, tendo publicações anteriores a esta limitação cronológica, consolidam o seu passo e se estabelecem como os escritores de referência do microconto brasileiro. Do mesmo modo, mencionaremos algumas produções publicadas na internet, mais propriamente em blogs pessoais e projetos de divulgação do microconto, atendendo a que, pelas suas características próprias (Ferreira, 2016), o microconto é um discurso que facilmente se propaga no meio virtual.

\section{O microconto brasileiro contemporâneo entre fronteiras}

Dividiremos nesta secção a nossa análise em dois grupos: por um lado, os continuadores, isto é, aqueles escritores que, tendo começado a publicação de livros de microcontos no século anterior, mantêm com relevância a sua atividade, e, por outra parte, aqueles escritores que debutam nas duas primeiras décadas do presente milénio. Apesar de não constituir um dos objetivos deste trabalho o esboço de um estudo diacrónico e evolutivo do microconto brasileiro, cremos que é importante partir da constatação que as origens desta categoria textual literária advêm das expressões modernistas e do impacto das inovações e experimentações vanguardistas que se deram tanto na poesia como na narrativa nas primeiras décadas do século XX. ${ }^{1}$ E esta afirmação vale tanto para o caso brasileiro como português, espanhol, hispanoamericano ou anglo-saxónico, por se tratar de um importante ponto de inflexão nas derivas e rumos da literatura contemporânea ocidental. De este modo, encontraremos no Brasil antecedentes importantes, como as Canções sem metro, de Raul Pompeia, a estética fragmentada e o carácter humorístico e subversivo - na base do conceito de pessimismo - da segunda etapa da produção ficcional de Machado de Assis (presente em obras como Memórias póstumas de Brás

\footnotetext{
${ }^{1}$ Não convém confundir os termos microconto e microficção, uma vez que este último é mais abrangente e engloba todos os textos ficcionais que se sujeitam a estruturas formais muito breves, como pode ser o microconto, o aforismo, o haiku, o poema em prosa, a trova ou a fábula, e as suas origens se remetem, portanto, aos próprios inícios da literatura.
} 
Cubas) e os poemas-piada surgidos também no modernismo. As primeiras manifestações encontrar-se-iam nos contos argelinos de Lima Barreto, publicados na Revista Souza Cruz, em 1924, e começariam a brotar com força nos anos 1960 com o "trio de Guaxupé" formado pelos escritores Elias José, Francisca Vilas-Boas e Sebastião Rezende.

Os autores que consolidam a sua produção literária no território do miniconto no novo milénio e que constituem hoje referências ineludíveis neste campo são três: Marina Colasanti, Dalton Trevisan e José Eduardo Degrazia. A referência a estes autores como os mais destacados da produção microficcional que transita entre séculos não é fortuita. Os três escritores não só partilham, como veremos, o gosto já consolidado pela escrita do breve, mas são também imprescindíveis para entender o microconto brasileiro nas suas três linhas ou direções particulares: o microconto fantástico e maravilhoso, o microconto de máxima contenção linguística e o microconto que corteja o discurso cronístico. Se bem que por uma questão prática de análise isolaremos cada uma destas tendências, o certo é que tal divisão é meramente orientativa, já que num mesmo autor ou obra podem confluir em simultâneo mais de uma destas tendências.

Marina Colasanti (1937-), formada em jornalismo e belas-artes, canalizou a sua vocação numa atividade literária extraordinariamente fértil e exigente, através da publicação de mais de 70 livros, entre crónicas, poesia, contos e microcontos. Escritora nómada no que se refere a uma afiliação genérica, é hoje uma das vozes mais destacadas do panorama literário infanto-juvenil brasileiro, marca esta que se reflete na sua obra microficcional, com o tratamento e escolha de temas que se aproximam amiúde ao imaginário infantil. A incursão de Colasanti pelo microconto tem a sua estreia em 1975 com a publicação do livro Zooilógico, seguindo-se A Morada do Ser (1978), Contos de amor rasgados (1986) e Hora de alimentar serpentes (2013). Muito embora a amplitude temporal que os distancia (mais de três décadas), estes quatro livros registam um estilo e uma voz que permanece fiel aos seus inícios, divergindo ocasionalmente nas temáticas e conteúdos particulares de cada livro. Se em Zooilógico entramos no terreno do bestiário e da fábula, com evidentes códigos paródicos e humorísticos, vemos como esses mesmos códigos são estruturantes no tratamento do doméstico e do corpo na obra A morada do Ser, no íntimo e feminino em Contos de amor rasgados e na obra que nos interessa fazer menção, muito afim a uma poética de homenagem ao universo cultural recebido, Hora de alimentar serpentes.

Falar da obra microficcional de Colasanti passa necessariamente por aludir ao uso lúdico e artificioso da linguagem, não somente pela transformação paródica de que é alvo grande parte das referências temáticas usadas e de procedência tão diversa - como podem ser os textos literários mais canónicos, e aqueles oriundos da tradição popular - como também pelo emprego de mecanismos de desautomatização de convenções linguísticas, a favor de uma libertação de pactos de escrita e do próprio pensamento. No fundo, os microcontos de Marina questionam continuamente os modos de normatização e apropriação cultural e linguística. Se no caso do carácter transgressor a nível temático isso é visível em mecanismos como a paródia e o pastiche - recorrendo às acepções de Genette (1989) -, no caso dos processos de transformação linguística, Marina joga com palavras e expressões de sentido amplo e ambíguo, permitindo-lhe criar desvios nas expectativas leitoras. Esta mesma atitude de transgressão de base temática e linguística é análoga a outras autoras imprescindíveis do microconto latino-americano, como é o caso das argentinas Ana María Shua e Luisa Valenzuela. Vejamos:

Primeira História de Insônia

Porque o sono se recusa a emantá-lo na cama, um homem começa a contar carneiros. Do que se aproveita o lobo, para deslizar sorrateiro na cena e posicionar-se, boca aberta, do outro lado da cerca (Colasanti, 2013, p. 33).

Que nada se desperdice

A mulher que deitada na cama ao lado do marido procura o sono, está imóvel. É nessa imobilidade que o desejo, sem ter sido convocado, lança seu apelo, e se apropria dela lentamente. Sem toque ou gesto que a denuncie, a mulher se acende. Dessa luz se aproveita o marido para ler um pouco, antes de dormir (Colasanti, 2013, p. 129). 
O primeiro exemplo corresponde ao primeiro de vários textos, dispersos pelo livro, que atualiza e joga com a expressão "contar carneiros". Transgredindo esse carácter inamovível das expressões, este microconto coloca os personagens da expressão em situação e dota-lhes de um sentido cómico inesperado, com feições próximas à fábula, ao bestiário, ou mais ainda aos contos de fadas, pela presença humana e pelo animal que aparece com frequência neste tipo de histórias, o lobo. O segundo exemplo utiliza a mesma técnica de desautomatização da linguagem, neste caso recorrendo ao uso metafórico que o verbo "acender" possui em contexto erótico (equivalente ao phrasal verb inglês to turn somebody on), para desconstruir as expectativas e criar um final subitamente absurdo e imprevisto, com o recurso ao sentido original e literal desse mesmo verbo. Em consequência, o desfecho da ação não se encontra na consumação do ato sexual, mas sim numa conversão da figura feminina numa espécie de candeeiro.

Estes dois exemplos parecem-nos significativos para justificar essa dimensão de transgressão e desautomatização em Marina Colasanti, conseguidos através do procedimento de reescrita e ressemantização do código linguístico e literário. Não obstante, nem sempre ocorre essa atitude desconstrutora, cabendo uma visão privilegiada do microconto como lugar onde podem convergir, em gesto de homenagem e cortesia, vários textos e discursos num mesmo fragmento:

A questão é Eça

Um barco nunca está imóvel, nem mesmo quando atracado ao cais. Assim pensa Ulisses, sentado diante do mar numa rocha na ilha de Ogígia, com a barba enterrada entre as mãos. Um barco - pensa ele - nunca está parado, ainda que preso ao fundo pela âncora. Um barco - ele sabe - é sempre possibilidade de viagem. Viajou tanto, Ulisses, e agora se vê preso pela vontade dos deuses na imobilidade pétrea dessa ilha. Preso ao corpo e ao desejo de Calipso sempre inalterados, à ausência de surpresa no leito em que sequer os lençóis se amarfanham. Piores são esses sete anos de escravidão erótica - pensa ele - do que os dez anos passados em lutas diante das muralhas de Troia. Melhor seria tê-la perdido. E se arrepende, quase, de ter inventado o Cavalo. Necessário seria pedir clemência aos deuses, sacrificando em sua honra uma rês com os chifres recobertos de ouro, não sem antes purificarse com a límpida água. Não conhece, Ulisses, outra maneira de obter a simpatia dos que, no Olimpo, determinam sua sorte. Mas como - pergunta-se o herói - afundar o machado no pescoço da rês e deixar jorrar na bacia seu negro sangue, se nada, nada nesta ilha encantada nasce ou morre? (Colasanti, 2013, p. 71).

Como é facilmente detectável, o microconto acima transcrito evoca o discurso mitológico patente na Odisseia de Homero, mais precisamente a passagem e larga permanência de Ulisses na ilha da ninfa Calipso. Porém, o título faculta-nos outras duas pistas: não em vão aparece Eça, em vez do demonstrativo homófono "essa". Eça de Queiroz (1983) possui um conto chamado "A perfeição", em que se relata precisamente o modo como Ulisses conseguiu sair da ilha, depois de ser testemunho ao longo de vários anos de uma perfeição imutável e demasiado monótona tanto da ilha como da própria Calisto. Por outro lado, intitular "A questão é Eça" recorda-nos a expressão pela qual se tornou famosa a peça A tragédia de Hamlet, "Ser ou não ser. Eis a questão", em que Hamlet (1984) discorre sobre qual a posição que deve afrontar: seguir e deixar-se levar pelos desígnios superiores ou arriscar e insurgir-se contra o destino. Conectar estes três universos não constitui apenas um ato de união de textos literários tão diferentes quanto as épocas que abarcam; é conferir-lhe uma longitude mais totalizadora, fazendo convergir num texto tão curto, as dimensões filosófica, mitológica e dramática.

Por outras rotas transita a obra de Dalton Trevisan (1925-), Prémio Camões 2012 e outro autor de referência obrigatória nos estudos do microconto brasileiro. Dentro da prolífica produção literária, iniciada nos anos 1940, Arara bêbada (2004), 99 carnívoras nanicas (2007), Maníaco de olhos verdes (2008), Duzentos ladrões (2008), 111 Ais (2010) e Desgracida (2010) correspondem aos títulos que incluem nas suas páginas textos que podemos catalogar de microcontos. As suas "mini-histórias"2 nos trasladam a uma espécie de realismo sujo, por fazêlas derivar em textos que dão primazia ao coloquialismo minimalista e ao poder simbólico dos

\footnotetext{
${ }^{2}$ Terminologia cunhada pelo próprio autor, no seu livro Desgracida (2010), para referir-se aos seus microcontos.
} 
cenários que esboça para retratar os problemas sociais que assolam o espaço urbano, e que vão desde a desintegração do núcleo familiar à própria decadência das relações humanas, expressa numa denúncia corrosiva e sarcástica, e muitas vezes acompanhadas de humor negro e grotesco, do machismo, do sádico, da repressão, da violência e da condição submissa da figura feminina. A extrema parcimónia linguística, conjuntada com as componentes humorística e sarcástica fazem aproximar estes textos por vezes ao aforismo e a outro género particular brasileiro surgido no modernismo, o poema-anedota.

Uma Loucinha

- A fulana abandonou essa aí desde que nasceu. Pra ela sou a única mãe.

- Da outra nem se lembra.

- Agora a desgracida quer a menina...

- Ah, não.

- ...assim que faça dez anos.

- E disse...

- ...por quê?

- ?

- Aí já lava uma loucinha (Trevisan, 2010, p. 151).

O Braço Armado

O filho é o braço armado da mãe contra o monstro do pai (Trevisan, 2010, p. 91).

\section{O Ronco}

O seu tormento era o ronco do marido. Gorducho, pança no ar, bocarra aberta. E roncava ralo gorgolejante de pia, um afogado nos estertores do sufoco, sororoca de hiena papuda. Inútil beliscar, sacudir, ofender. Certo, mudava de posição - e roncava.

Até que, feliz dela, morreu. Para não ficar só, a mulher comprou um lindo buldogue branco e mosqueado. Carantonha amassada de mau pugilista. Garboso na sua majestade bamboleante. Dormia no corredor, ao lado do quarto. Gorducho, pança no ar, bocarra aberta. E roncava. Mais alto que o outro. Para a viúva era suave música, que a embalava em sonhos de vida nova, novos amores (Trevisan, 2010, p. 135).

A decadência que tanto assola o ambiente desta obra - e das obras do escritor curitibano no geral - está intimamente ligada a uma morbidade sexual, à degeneração dos vínculos entre casais e entre pais e filhos, aos jogos de poder e de dominação do homem com respeito à mulher, género último prejudicado pela acumulação insensata de deveres e responsabilidades impostos por uma sociedade altamente patriarcal, e que é posta em evidência pelo adjetivo que dá nome a esta obra, desgracida. Como se não bastasse, este estado degenerativo vê-se refletido no próprio código linguístico, estando explicitamente denunciado pelo narrador em peças como "A Língua dos Caras":

A Língua dos Caras

$1^{\circ}$ - Ninguém mais tem nome. Somos todos - cara, ei, cara. Até entre as moças.

$2^{\circ}$ - Todos os adjetivos se resumem a um só - legal.

$3^{\circ}$ - Não se conjuga verbo. É só - a gente diz, a gente isso, a gente aquilo.

$4^{\circ}$ - Machista, a garota só diz - obrigado.

$5^{\circ}$ - Toda frase tem o palavrão - porra. Mais de uma vez.

$6^{\circ}$ - A regência dos verbos é única - eu lhe vejo, eu the adoro, eu the mato.

$7^{\circ}$ - Os doutos de fala pomposa - a somatória...houveram muitos aplausos...

$8^{\circ}$ - Em cada frase a repetição do sujeito - o fulano, ele... a escola, ela... (Trevisan, 2010, p. 129).

A última tendência que marca o microconto brasileiro tem que ver com a sua forte proximidade com a crónica. Tal afirmação não é de todo inesperada, se tivermos em conta que esta categoria textual possui uma "tendência a disfarçar-se sob a forma de outros discursos" (Fialho, 2008, p. 17) ou que usa a "contaminação como recurso criativo" (Bustamante Valbuena, 2016), que faz com que se aproprie e adopte características de vários géneros, literários e extraliterários. Por outra parte, no caso da contiguidade com a crónica, tampouco é casual que 
tal suceda nas Letras Brasileiras (Schøllhammer, 2004). Como José Nêumanne refere no prefácio à obra A grande ilusão, de Luiz Fernando Emediato (1992), a crónica possui bastante representatividade no Brasil, tornando-se indispensável abordá-la em qualquer aproximação que se faça à Literatura Brasileira Contemporânea:

Uma das peculiaridades bem brasileiras é a crônica [...]. É um gênero de vadiagem literária. [...] O certo é que a crônica não tem nada a ver com a proliferação de romances de literatura espanhola, o rigor formal da poesia inglesa ou o profissionalismo mercadológico do conto americano (Nêumanne, 1992, s.p.).

Factos quotidianos contados com uma linguagem enxuta, levando-os por vezes ao território do absurdo e à criação de uma espécie de reportagens narrativas, e que dão conta de crimes ou situações urbanas particulares que refletem as vivências sociais são algumas das marcas que podemos encontrar num número significativo de microcontos de José Eduardo Degrazia (Porto Alegre, 1951-), sobretudo nas suas primeiras obras de microcontos, como O atleta recordista (1996) em que, aliás, os últimos microcontos se parecem e muito às Notícias em três linhas, de Félix Fénéon (2018) - e A orelha do bugre (1998). A sua última obra, A colecionadora de corujinhas (2016), contém textos como "De Garopaba ao Nepal" e "O guri chorão", que colocam em evidência a necessidade de retratar uma realidade que o leitor sem esforço reconhece como pertencente a um mundo que tem existência efetiva e que até pode, ou não, ser-lhe familiar e próximo:

De Garopaba ao Nepal

Tinha vinte anos no início dos anos 70 e vivia numa comunidade hippie em Garopaba. De noite tocavam violão e fumavam. Ao sol, quando acordavam antes do meio-dia, ajudavam os pescadores a recolher as redes cheias de peixes. Namorava uma guria de Erechim, loirinha. Recebia pontualmente a mesada que o pai mandava pensando que era para os estudos. Em síntese, o paraíso na Terra. Numa reunião na praia, à noite, em volta do fogo, tudo isso acabou de repente. A comunidade decidiu que ele deveria partir em peregrinação para Katmandu, para pagar alguma velha promessa. Não houve choro nem vela, deram-lhe uma passagem para o Rio de Janeiro, enfeitaram seus longos cabelos com flores, desejaram-lhe boa viagem. $\mathrm{Na}$ hora de embarcar no avião para o Oriente, desistiu. Não se sentia preparado para a missão que a comunidade lhe dera. No Rio de Janeiro deixou-se ficar entre Ipanema e Leblon, com surtidas à Gávea e à Barra. Vendeu sanduíches naturais, jogou búzios em Ipanema, leu tarô em frente ao Copacabana Palace. Quando o dinheiro não dava, prostituía-se numa boate da Vieira Souto. Num verão muito louco foi levado por um casal de americanos para uma viagem pelo Caribe. Acordou num hotel de Tijuana, numa ressaca terrível, sem dinheiro. Mesmo sendo de Bento Gonçalves, tocou berimbau em Acapulco e pandeiro em Aruba. Foi vaposeiro em Port-auPrince e leu poesia brasileira no Malecón de Havana. Perto dos trinta anos conheceu, num navio em que viajava pelo Caribe tocando maracas num grupo de salsa, rica herdeira de político baiano. Depois do sogro quase afogá-lo na piscina, casaram-se com champanhe e lagostas. Vinte anos após acordou numa manhã abafada de Salvador: tivera um pesadelo em que a antiga comunidade hippie dos tempos de Garopaba o estava julgando no Pelourinho, por não ter cumprido a promessa de ir a Katmandu, e por ter renegado os princípios da comunidade. Deveria morrer. Acordou assustado, o coração batendo, e pela primeira vez em vinte anos não vestiu o terno e a gravata. Tomou um copo de suco de laranja, botou uma sunga, correu à praia particular, que era de seu sogro, com coqueiros e caipirinha ao alcance da mão, e atirou-se ao mar. Nadou, nadou muito, nadou tanto que já não tinha a menor ideia de tempo e espaço. Passou pelo Cabo da Boa Esperança e se jogou na areia em Macau. Encontrou o caminho da Índia. Atravessou o Afeganistão fugindo das balas dos Talibãs. No norte da China foi reconhecido como profeta, as longas barbas brancas, os cabelos amarrados com flores. Assim chegou ao Nepal. A primeira coisa que fez foi beijar a terra. Declamou alguns mantras e ouviu longe, longe, os tambores dos templos budistas. Estava na Terra Prometida. Monges, vestindo amarelo e laranja, passeavam pelas ruas, bandos de Hare Krishna pulavam ao som dos tambores. E hippies, muitos hippies vivendo enfim o tempo de paz e amor. Caminhou pelas ruas até encontrar-se na frente de um palácio. Mas de lá não vinham músicas nem flores. A multidão raivosa atacava a guarda com pedras e pedaços de pau. Gritavam que haviam assassinado a Família Real. A tropa respondia com balas de borracha e outras não. 
Uma atingiu a testa do nosso herói. O povo o levantou do chão com respeito, era um santo. Foi cremado numa pira na montanha mais alta do Nepal. A fumaça atingiu o céu mais azul do mundo. Fez a volta em torno da Terra até chegar à praia de Garopaba. Surfistas, malucos, velhos hippies, entenderam (Degrazia, 2016, p. 9-10).

\section{O guri chorão}

Saiu da Faculdade quase noite, a bruma começando a envolver as árvores do Parque. Caminhou pela avenida até que ouviu um choro convulsivo. Um guri, de seus oito, nove anos, abraçado a uma cesta, chorava, lamentava-se em altos brados. Não se conteve e chegou perto dele, o coração tocado por tal demonstração de sofrimento. $O$ guri contou que havia vendido todos os pastéis que a mãe mandara vender. Ganhara cinquenta reais. Quando estava pronto para pegar o ônibus para casa, com o dinheiro no bolso, um ladrão passara correndo e levara todo o dinheiro. Chorou mais alto ainda. Tirou da carteira cinco notas de dez reais e deu para o guri. Puxou a mão que o pequeno queria beijar, e foi se afastando, sem olhar para trás, com secreta alegria no peito. No outro dia, como de costume, saiu do trabalho ao entardecer, caminhou pela avenida de sempre. Foi quando parou ao ouvir o mesmo choro da véspera. Ficou vendo um homem aproximar-se condoído do menino. Ouvir a história, botar a mão no bolso, tirar cinco notas de dez reais e dar para ele. Viu o homem afastar a mão da boca do guri e sair faceiro como se tivesse acertado na loteria. Desde este dia não fez mais o mesmo caminho. Não conseguia deixar de ouvir o choro, de ver a cena repetir-se. Mas não sentia pena nem raiva de si mesmo por ter feito o papel de otário. Era mais um personagem no drama da cidade. E o guri chorava com muito sentimento (Degrazia, 2016, p. 27).

\section{Os novos autores}

A inauguração do microconto brasileiro do novo milénio contou com o surgimento significativo em 2001 de um livro peculiar de Fernando Bonassi, Passaporte. Editado pela já extinta Cosac \& Naify, esta obra esgrima o conceito de livro-objeto para, através do seu formato e aparência de passaporte, transportar o leitor - nunca melhor dito - ao universo de uma literatura de viagens dominada pela narração de pequenas histórias ambientadas em cidades e espaços físicos concretos entre a América e a Europa. É sintomático que uma grande quantidade destas narrativas concentre a sua atenção numa realidade do quotidiano humano brasileiro e nos despojos humanos saídos da Segunda Grande Guerra, apoiada nas impressões deixadas no narrador ao visitar Alemanha e Polónia. As marcas de água presentes nas páginas de um passaporte não são descuradas e estão aqui presentes para representar graficamente cada um dos microcontos que fazem parte deste Passaporte. No seu conjunto, este livro patenteia e louva a ambiguidade de fronteiras entre discurso literário e escrita não literária, demarcando-se da mais viva tradição do microconto latino-americano, pela ausência do elemento fantástico e, em consequência, pela preferência de fórmulas próximas à crónica, ao texto testimonial e utilitário e desafiando a diluição de fronteiras entre discurso ficcional e não ficcional, entre livro como objeto estético e utilitário, entre ficção e memória:

003 turismo ecológico

Os missionários chegaram e cobriram das selvagens o que lhes dava vergonha. Depois as fizeram decorar a ave-maria. Então lhes ensinaram bons modos, a manter a higiene, e lhes arranjaram empregos nos hotéis da floresta, onde se chega de uísque em punho. Haveria uma lógica humanitária exemplar no negócio, não fosse o fato de as índias começarem a deitar-se com os hóspedes. Nada faz com que mudem. Seus maridos, chapados demais, não sentem os cornos. De qualquer maneira todos levam o seu. Só mesmo esse Deus civilizador é quem parece ter perdido outra chance (Bonassi, 2001, p. 3).

008 despojos de guerra 
O pai de Karin foi preso bem no dia 7 de maio de 1945. Ela tinha 6 meses. Os soviéticos queriam a forra de Leningrado sem vergonha e o mandaram pra Sos'va. Ninguém soube o que ele fez, a ponto de envergar todas as unhas pra sempre. No dia em que ele voltou, dez anos depois, com os últimos prisioneiros que Adenauer foi buscar em Moscou, a mãe de Karin tinha ido drenar pântanos perto de Oth-Marschen. Quando Karin viu aquele homem parado na porta, foi logo oferecendo um prato de comida, pois era o certo de fazer com estranhos na época (Hamburgo - Alemanha - 1998) (Bonassi, 2001, p. 8).

Também o prémio Jabuti 2004 (categoria "contos e crónicas"), Mínimos, múltiplos, comuns (2003/2015), de João Gilberto Noll (Porto Alegre, 1946-), ascende à categoria de obras fundamentais do microconto que surgem nestes anos. Publicados originalmente na Folha de $S$. Paulo, os 338 textos ali contidos fundem-se numa precisão linguística que leva a uma expressiva capacidade visual e intimista da palavra e a uma explicitação do sentido do texto. Esta última característica é o que leva à denominação de "instantes ficcionais" ou "romances mínimos", numa clara rejeição de tipologias convencionais, mas que valoriza a máxima expressão e potencial narrativo dentro de um limite de 130 palavras. Ao contrário do que é frequente no microconto, João Gilberto Noll não procura jogar com as expectativas leitoras, apostando na procura da sinceridade e de uma verdade poética:

Água

Perdi-me na mata. Encontrei macacos, gatos silvestres, laivos de feras. De repente, uma trilha. Adiante uma tapera. Ó de casa, bato palmas. Da porta surge uma mulher. Por favor, eu digo. Sim, ela responde. E arrisca: Sede? É, é isso, respondo cheio de vontade de um copo d'água. É o que em segundos tenho. Bebo a água me pingando todo pelo peito. Um refrigério que meu pai exibia aos domingos. É verão?, pergunto. Aqui sempre é, ela responde. E agora nada mais que esse silêncio alfinetando alguma coisa parada entre nós dois, ali. Atrás da pedra um lagarto expande seu sono ao infinito (Noll, 2015, p. 73).

Outro autor preponderante desta nova geração de escritores é Leonardo Brasiliense (São Gabriel, 1972-). Tendo estreado em 2000 com Meu sonho acaba tarde, publicou, em 2007, Adeus conto de fadas, tendo sido agraciado também com o prémio Jabuti na categoria de contos desse ano e, em 2014, Corpos sem pressa. Nos seus textos predomina a autorreferencialidade ou a manifestação explícita de códigos e elementos da escrita literária e não literária (como pode ser a economia linguística, a voz do narrador) e uma preferência por temas do quotidiano e com um sentido realista patente, em que a ironia adopta protagonismo enquanto recurso de exorcismo dos males do homem de hoje e das convenções sociais. Se em Adeus conto de fadas encontramos com frequência personagens juvenis que confrontam os seus dilemas, contrariedades e preocupações - daí o título que evoca o fim da etapa das histórias idílicas infantis e a frase aforística que encerra o livro "Ser criança era moleza" -, em Corpos sem pressa arremete para uma dimensão mais comprometida, presente na denúncia dos problemas relacionados com as classes sociais mais desfavorecidas, tomando a violência, nas suas mais diversas manifestações, o tema com mais relevância:

Finalmente...

...depois de anos sem notar que eu existia, ele vem sorrindo na minha direção. É o intervalo entre a aula de matemática e a de português, e que ninguém me pergunte quanto é $2+2$ nem se paixão é com $x$ ou ch, porque agora eu não saberia mesmo dizer. A Flavinha vive me criticando porque eu dou muito na vista, que eu não devo parecer fácil, tenho que esconder meus verdadeiros sentimentos... Mas a prova de que ela está errada vem vindo na minha direção e me encarando e sorrindo e tirando um papelzinho do bolso:

- Entrega pra Flavinha, faz favor (Brasiliense, 2007, p. 31).

\section{Solidariedade}

Numa esquina da avenida mais movimentada, às sete da noite, o sinal fica verde, entretanto a carroça do papeleiro não se mexe. Os motoristas começam a buzinar. $\mathrm{O}$ papeleiro agita as rédeas, faz um som esquisito com a boca, e nada adianta. O cavalo 
empacou. Os motoristas, já numa fila de incontáveis faróis e buzinas, com o que lhes resta de forças depois de mais um dia cansativo e estressante em seus escritórios e repartições, gritam, xingam, amaldiçoam. O papeleiro, por sua vez, com o que lhe resta de fôlego depois de mais um dia de sol pelas ruas da cidade, os braços fracos de abrir lixeiras desde as seis da manhã, desce da carroça empunhando um cabo de vassoura e grita, bate, espanca. E o cavalo, com o que lhe resta de si depois de mais um dia que ele nem sabe que passou, com a fome de hoje somada à de ontem e anteontem que o deixam lerdo e confuso, ajoelha-se, de olhos fechados, como quem reza para morrer (Brasiliense, 2014, p. 25).

Em termos gerais, uma parte significativa dos novos autores apostam por jogar com uma circunscrição formal mais ou menos rígida, devido a uma prática que se tornou particularmente muito frequente na produção escrita no Brasil e que tem muito que ver com o uso das novas tecnologias e das oficinas de escrita criativa enfocadas numa apropriação dos meios tecnológicos para a produção literária. Dois exemplos evidentes são as produções dos escritores José Rezende Junior (Aimorés, 1959-), cujos textos, carregados de ironia e sátira e debruçando-se sobre a solidão, as paixões humanas, encontros e desencontros amorosos, não excedem os 140 caracteres, e de Edson Rossatto (São Paulo, 1978-), o qual, com Cem toques cravados (2010), manifestou a sua predileção por uma escrita lúdica com textos de extensão exata de 100 caracteres cada. Algumas das peculiaridades que encontramos nestes textos residem na propensão aos trocadilhos, jogos de palavras, paradoxos, mas também manifestam por vezes um minimalismo demasiado simplificador.

Maternidade

A gravidez, tranquila. O parto, rápido e indolor.

As dores foram depois - e para a vida inteira (Rezende Junior, 2010, p. 26).

Só se vive muitas vezes

Nada contra a reencarnação. O triste é começar tudo de novo. Sabe quantos primeiros amores eu já sofri nessas vidas? E toda vez dói (Rezende Junior, 2010, p. 66).

Numa mesma linha da extrema redução do enunciado textual aparece em 2016 a última obra de João Anzanello Carrascoza (Cravinhos, 1962-), Linha única, com textos como os seguintes:

Marca

Evitava bater no rosto. A alma, um vergão só (Carrascoza, 2016, p. 63-64).

Fé

Leu o salmo 27, pegou o revólver e foi assaltar o banco (Carrascoza, 2016, p. 91-92).

Outra grande novidade do novo milénio foi o surgimento das primeiras antologias de microcontos, circunstância inaugurada por Marcelino Freire em Os cem menores contos brasileiros do século (2004). Tal como o título deixa entrever, é um livro que se demarca pela máxima contenção linguística, reunindo para o efeito a colaboração de cem escritores. $\mathrm{O}$ apelativo de transmitir algo com a mínima expressão verbal foi determinante para cativar e contagiar vários autores, ao ponto de hoje ser uma das tendências do microconto brasileiro, contando também como grande contributo à imersão e à difusão do processo criativo na internet, o uso dos novos dispositivos tecnológicos e a proliferação de oficinas de escrita criativa. Os exemplos que se seguem são da autoria de Beto Villa e Cíntia Moscovich, respectivamente:

12

- Diz que me ama.

- Aí é mais caro (Freire, 2004, p. 12). 
16

Uma vida inteira pela frente.

O tiro veio por trás (Freire, 2004, p. 16).

Numerosas antologias seguiram-se a esta, publicadas sob diversos temas, como as da editora Casa Verde: Contos de bolso (2005), Contos de bolsa (2006), Contos de algibeira (2007), Contos comprimidos (2008); a antologia de microcontos de Laís Chaffe e Marcelo Spalding, Minicontos e muito menos (2009); a antologia pessoal de Ana Mello, Minicontando (2009); e a antologia de microcontos de humor 80 contos sem desconto, de Adair Philippsen (2012). Também Edson Rossatto, editor de Andross (São Paulo), organizou várias antologias como Expresso 600: 61 microcontos de vários autores (2006), Retalhos: contos e microcontos (2007), Entrelinhas: antologia de contos e microcontos (2008), Histórias liliputianas: antologia de microcontos (2010). Do mesmo modo surgiu em 2005 Brevíssimos!, uma antologia organizada por Charles Kiefer e publicada pela editora Bestiário; e em 2013 a Penalux publicou Contos mínimos S/A, organizada por Lohan Lage Pignone. De salientar que uma parte considerável destas antologias brota do convite dos editores à escrita por encomenda, não havendo uma seleção prévia dos textos.

Ainda dentro do mercado editorial, cabe destacar igualmente o nascimento de chancelas dedicadas exclusivamente à escrita hiperbreve, como o selo "Três por Quatro", da editora Multifoco, que já publicou mais de uma dezena de títulos de microcontos, e "Microlux", selo da editora Penalux.

Se nos adentramos no mundo da internet, apercebemo-nos de uma expansão muito patente destas formas, dando a entender que este meio virtual serve de potente veículo de difusão (Souza e Rodrigues, 2012, p. 79). São vários os blogs que podemos encontrar que de algum modo deram visibilidade a autores que se estrearam na internet, antes que com publicações em suporte papel. Dentro da dispersão caótica deste fenómeno, alguns blogs que nos podem servir de referência do microconto publicado na internet são os de Cláudio Costa, Micronarrativa, microcontos, nanoconto; ${ }^{3}$ o de Wendell Guiducci; 4 o de Thiago Moralles; 5 o de Lidiane Nunes, Deslocamentos; 6 Microrelatos do Cheeko; $;$ e o de Jarbas Novelino Barato, Primeiros mil microcontos. ${ }^{8}$ Damos alguns exemplos do blog ainda em atividade Homem de palavra, de Mário Baggio, da sua secção de "contos mínimos":

836.

Tudo tem seu antônimo, seu contrário, seu oposto. Sua nêmesis. Do mesmo modo que a Bela Adormecida precisa de um príncipe que a desperte com um beijo, existe em algum lugar do mundo uma Feia Insone que há uma eternidade espera que um príncipe a beije para, finalmente, dormir (Baggio, 2017a, s.p.).

826.

Foi num desses dias, prenhes de normalidade, quando nada sinalizava a perturbação da ordem, que tudo aconteceu. No meio da sala, depois do jantar, comecei a diminuir de tamanho. Primeiro, cheguei à altura da mesa, depois à do sofá, em seguida à do banquinho onde costumava pôr os pés. Fui reduzindo, encolhendo, murchando, quase derretendo. Como era de se esperar, tudo em volta se agigantou, até o Pingo, que me mostrou os dentes, mas sossegou depois de me cheirar. Meu filho de cinco anos, que montava um quebra-cabeças no chão, olhou pra mim e começou a gargalhar: "Olha o papai, tá mais

\footnotetext{
${ }^{3}$ Disponível em: http://micro-pilulas.blogspot.com

${ }^{4}$ Disponível em: http://curtoeosso.blogspot.com.es/

${ }^{5}$ Disponível em: http://tfmoralles.blogspot.com.es/search/label/Microcontos

${ }^{6}$ Disponível em: http://nuneslidi.blogspot.com.es/search/label/Minicontos

${ }^{7}$ Disponível em: http://microrelatosdocheeko.blogspot.com

${ }^{8}$ Disponível em: ttp://terceirosmicrocontos.blogspot.com
} 
pequenininho que eu!". Minha mulher, que fazia crochê enquanto aguardava a novela começar, tirou os óculos e me encarou: "Você está se sentindo bem?" (Baggio, 2017b, s.p.).

\section{7.}

Naquela manhã o inseto despertou transformado em homem. Na frente do espelho, o que ele viu o enojou. Sentiu um asco infinito, uma insuportável náusea, uma repugnância que desconhecia limites. Teve saudade do tempo em que era apenas uma barata, mesmo conhecendo do que os humanos eram capazes de fazer com as baratas. Resignado com a condição em que ora se encontrava, apertou o nó da gravata e ganhou a rua. Misturou-se à multidão de humanos e baratas, arrastando tripas e misérias pelas calçadas, disposto a pisar e a ser pisado (Baggio, 201c7, s.p.).

Por outra parte, cabe destacar o trabalho realizado pelos professores universitários Marcelo Spalding, Ana Mello e Maurem Kayna, através da criação das páginas Minicontos.com.br ${ }^{9}$ e Literatura Digital. ${ }^{10} \mathrm{Em}$ ambas se encontra um importante repositório bibliográfico e um fórum de divulgação e discussão daquilo que supõe a leitura e a produção literária na Era Digital, pretendendo fomentar a atenção para os textos nativos dos novos suportes tecnológicos, como o iPad, Android ou o Kindle. Centramos a atenção em alguns projetos referidos na página Literatura Digital, como Microcontos coloridos, em que se representa a criação de microcontos através da mistura de cores que o utilizador selecione previamente. ${ }^{11}$ Outros dois projetos de carácter minimalista que se aludem nesta mesma página são os do curitibano Samir Mesquita, Dois palitos (2007) e 18:30 (2009). Dois palitos é uma obra que simula a forma de uma caixa de fósforos, em que o utilizador acede à leitura de microcontos de no máximo 50 caracteres pela seleção e figura da combustão dos fósforos que compõem essa mesma caixa (Figura 1).

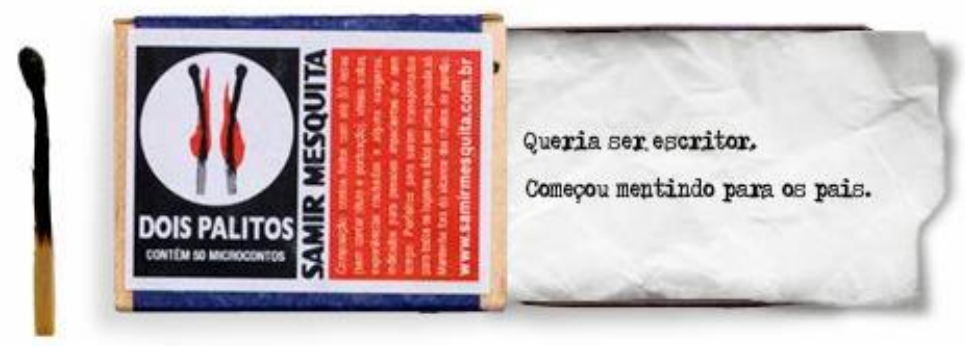

Figura 1 - Microconto em Dois palitos (Mesquita, 2007, s.p.).

Já 18:30 alcança a representação da frenética contemporaneidade invocando a representação de um congestionamento de trânsito, inspirado no caos que ocorre com frequência na cidade onde o próprio autor trabalha, São Paulo. Os enunciados, incorporados nalguns dos carros presentes no cenário da aplicação, correspondem a desabafos, frustrações e comentários de hipotéticos ocupantes das viaturas que conformam o congestionamento. Se o carácter coloquial e informal constitui a tónica destes enunciados, não menos significativa é a presença de jogos linguísticos que os povoam, embora o conceito estético destes enunciados possa ser questionável.

Por último, cremos importante falar da plataforma Portal dos Microcontos, ${ }^{12}$ desenvolvida por Carlos Seabra, que pretende difundir o que se está a desenvolver no que respeita o microconto em língua portuguesa na internet. Entre os vários projetos hospedados na plataforma, detenemo-nos em MiQRocontos, ${ }^{13}$ um software que personifica um modelo de exploração do

\footnotetext{
${ }^{9}$ Disponível em: http://www.minicontos.com.br/

${ }^{10}$ Disponível em: http://literaturadigital.com.br/

${ }^{11}$ Disponível em: http://www.literaturadigital.com.br/minicontoscoloridos/

${ }^{12}$ Disponível em: http://microcontos.com.br/

${ }^{13}$ Disponível em: http://seabra.com/qrcontos/
} 
código visual. Fruto da compilação de microcontos muito breves de autores que participaram com os seus textos na revista portuguesa Minguante e na revista brasileira Veredas, este projeto tem por base o uso de software de leitura de código QR para chegar à leitura do microconto encriptado (Figura 2).

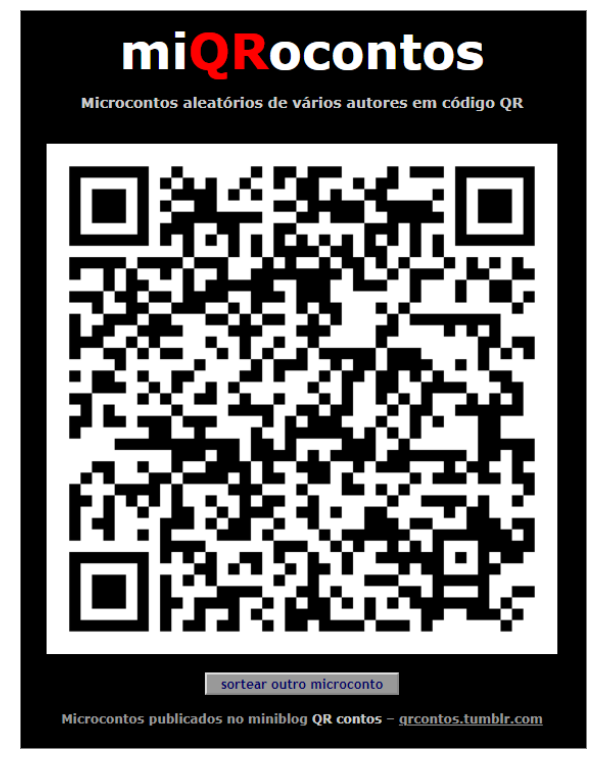

Figura 2 - Código QR da página de MiQRocontos.

A modo de conclusão, cremos que o microconto brasileiro mais recente tem evidenciado uma expansão, quer no número de autores e obras, quer na diversidade de propostas. Se bem que todo este processo de democratização da escrita - especialmente visível na navegação por internet -, aliado à ideia preconcebida de que escrever microcontos é uma tarefa fácil, tem afetado a qualidade dessas propostas, o certo é que também veio dar uma certa dinâmica e a mobilizar comunidades de leitura e de escrita cada vez mais interessadas neste fenómeno literário.

\section{Referências}

ALMEIDA, Márcio (2010). A minificção do Brasil: em defesa dos frascos \& dos comprimidos. Oliveira, MG: Clube dos Autores.

BAGGIO, Mário (2017a). Contos Mínimos \# 831 a 840. Homem de Palavra: o blog do Mário Baggio, São Paulo, 28 nov. On-line. Disponível em: http://homemdepalavra.com.br/contos-minimos-831-840/ Acesso em: 25 ago. 2018.

BAGGIO, Mário (2017b). Contos Mínimos \# 821 a 830. Homem de Palavra: o blog do Mário Baggio, São Paulo, 7 nov. On-line. Disponível em: http://homemdepalavra.com.br/6331-2/ Acesso em: 25 ago. 2018.

BAGGIO, Mário (2017c). Contos Mínimos \# 811 a 820. Homem de Palavra: o blog do Mário Baggio, São Paulo, 23 out. On-line. Disponível em: http://homemdepalavra.com.br/contos-minimos-811-820/ Acesso em: 25 ago. 2018.

BONASSI, Fernando (2001). Passaporte. Rio de Janeiro: Cosac \& Naify.

BRASILIENSE, Leonardo (2007). Adeus conto de fadas. Rio de Janeiro: 7 Letras.

BRASILIENSE, Leonardo (2014). Corpos sem pressa. Porto Alegre: Editora Casa Verde. 
BUSTAMANTE VALBUENA, Leticia (2016). La contaminación como recurso creativo en el microrrelato. In: ÁLVAREZ RAMOS, Eva; MARTÍNEZ DEYROS, María (Orgs.). Historias mínimas, estudios teóricos y aplicaciones didácticas del microrrelato. Valladolid: Cátedra Miguel Delibes. p. 151-168.

CARRASCOZA, João A (2016). Linha única. São Paulo: Editora SESI-SP.

COLASANTI, Marina (1975). Zooilógico. Rio de Janeiro: Nórdica.

COLASANTI, Marina (1978). A morada do ser. Rio de Janeiro: Civilização Brasileira.

COLASANTI, Marina (1986). Contos de amor rasgados. Rio de Janeiro: Rocco.

COLASANTI, Marina (2013). Hora de alimentar serpentes. São Paulo: Global Editora.

DEGRAZIA, José Eduardo (1996). O atleta recordista. Porto Alegre: Movimento.

DEGRAZIA, José Eduardo (1998). A orelha do bugre. Porto Alegre: Movimento.

DEGRAZIA, José Eduardo (2016). A colecionadora de corujinhas. Porto Alegre: Bestiário.

DEGRAZIA, José Eduardo (2018). Notícias em três linhas. Porto: Exclamação.

FERREIRA, Ana Sofia Marques Viana (2016). Potencialidades del microrrelato em internet. Revista Matlit, Coimbra, v. 4, n. 2, p. 207-231.

FIALHO, Henrique Manuel Bento (2008). Esboço para um ensaio sobre micronarrativa. In: COSTA, Rui; SEBASTIÃO, André (Orgs.). Primeira antologia de micro-ficção portuguesa. V. N. Gaia: Êxodus, p. 9-19.

FREIRE, Marcelino (Org.) (2004). Os cem menores contos brasileiros do século. São Paulo: Ateliê.

GENETTE, Gerard (1989). Palimpsestos: la literatura en segundo grado. Tradução de Celia Fernández Prieto. Madrid: Taurus.

MESQUITA, Samir (2007). Dois palitos. Disponível em: http://www.samirmesquita.com.br/doispalitos.html. Acesso em: 15 set. 2018.

MESQUITA, Samir (2009). 18:30. Disponível em: http://www.samirmesquita.com.br/. Acesso em: 15 set. 2018.

NÊUMANNE, José (1992). Prefácio. In: EMEDIATO, Luiz Fernando. A grande ilusão. São Paulo: Geração.

NOGUEROL, Francisca (1996). Micro-relato y posmodernidad: textos nuevos para el final de milenio. Revista Interamericana de Bibliografía, Sevilla, n. 1-4. On-line. Disponível em: https://bit.ly/2NlQkyo. Acesso em: 15 set. 2018.

NOLL, João Gilberto (2003/2015). Mínimos, múltiplos, comuns. 2. ed, Rio de Janeiro: Record.

QUEIROZ, Eça de (1983). A perfeição. Contos. Lisboa: Livros do Brasil.

REZENDE JUNIOR, José (2010). Estórias mínimas. Rio de Janeiro: 7 Letras.

ROSSATO, Edson (2010). Cem toques cravados. São Paulo: Andross.

SCHØLLHAMMER, Karl Erik (2004). Miniatura e fragmento: brevíssima incursão pelas formas breves do Brasil. In: NOGUEROL, Francisca (Org.). Escritos disconformes. nuevos modelos de lectura. Salamanca: Ediciones Universidad de Salamanca. p. 153-162.

SEABRA, Carlos (2015). MiQRocontos. Disponível em: http://seabra.com/qrcontos. Acesso em: 15 set. 2018.

SHAKESPEARE, William (1984). Hamlet. Príncipe da Dinamarca. São Paulo: Ediouro.

SOUZA, Fabrina Martinez de; RODRIGUES, Rauer Ribeiro (2012). A ascensão do microconto brasileiro no início do século XXI. In: ÁLVARES, Cristina; KEATING, Maria Eduarda (Orgs.). Microcontos e outras microformas. Minho: Húmus. p. 73-80.

TREVISAN, Dalton (2004). Arara bêbada. Rio de Janeiro: Record.

TREVISAN, Dalton (2007). 99 carnívoras nanicas. Porto Alegre: L\&PM Pocket.

TREVISAN, Dalton (2008). Duzentos ladrões. Porto Alegre: L\&PM Pocket.

TREVISAN, Dalton (2008). Maníaco de olhos verdes. Rio de Janeiro: Record. 
TREVISAN, Dalton (2010). 111 Ais. Porto Alegre: L\&PM Pocket.

TREVISAN, Dalton (2013). Desgracida. Rio de Janeiro: Record.

\section{Nota}

Os resultados deste trabalho foram financiados pelo Programa de Formación de Profesorado Universitario (FPU) do Ministerio de Educación, Cultura y Deporte (Espanha). 